\title{
Chapter 9 \\ Modeling Avian Distributions and Niches: Insights into Invasions and Speciation in Birds
}

\author{
Darius Stiels and Kathrin Schidelko
}

\begin{abstract}
Avian evolutionary studies have recently benefited from a plethora of new techniques as well as conceptual progresses on the evolution of ecological niches. The so-called species distribution models (SDMs) allow for niche quantifications in a way that permits comparisons among species and populations. This review will introduce the theoretical background of niche concepts and niche conservatism, followed by an outline of popular methods for modeling and analyzing environmental niches. A comparison of ecological niches among native and non-native populations of invasive species can reveal niche shifts. They can point to evolutionary changes that evolved over comparatively short time scales of decades to a few centuries. On the other hand, ecological niches can also remain conserved over the invasion process. In a similar way, comparisons of ecological niches are also applicable among closely related taxa. Thereby, it is possible to infer changes of ecological niches over longer time scales and reveal otherwise hidden patterns and processes in the evolutionary history of avian clades. Finally, SDMs offer the potential to contribute to integrative taxonomic studies.
\end{abstract}

Keywords Niche evolution · Niche conservatism · Birds $\cdot$ Species distribution model $\cdot$ Ecological niche model $\cdot$ Invasive species $\cdot$ Phylogeography

\subsection{Introduction}

Birds have conquered nearly every terrestrial corner of the planet and even soar and feed over the oceans. However, bird species are not uniformly distributed and often differ in their ecological niches. Current individual ranges are the result of tightly linked evolutionary history processes, like speciation, and ecological factors, like climate. Today, these factors are complemented by human influences. Thus, the study of distributional patterns and their underlying processes is at the core of

D. Stiels $(\bowtie) \cdot K$. Schidelko

Section Ornithology, Zoological Research Museum A. Koenig, Bonn, Germany

e-mail: d.stiels@leibniz-zfmk.de 
fundamental ornithological research, but also not less than a paramount challenge under global change. Here, we review one particular tool in the study of avian distributions and ecological niches: species distribution models (SDMs). SDMs or ecological niche models (ENMs) have become a standard tool in various fields of biology including ecology, evolution, conservation biology, and related fields (e.g., Elith and Leathwick 2009; Elith et al. 2006; Graham et al. 2004a; Guisan and Thuiller 2005; Guisan et al. 2013; Jeschke and Strayer 2008; Pearman et al. 2007; Peterson et al. 2011). Both terms, SDMs and ENMs, might slightly differ in their emphasis-whether the geographical distribution or the niche is in focus-but are regularly used as synonyms (Peterson and Soberón 2012). Given the in-depth knowledge and the great interest in birds, SDMs are now widely used in ornithology. Only recently, avian niche models and their applications were extensively reviewed (Engler et al. 2017). In contrast to this exhaustive overview, we will limit our focus to applications for the study of avian niche evolution and niche conservatism and its implications for research on speciation and invasive species. Prior to this, we start with a few basic concepts for those who are not familiar with the general background of SDMs.

\subsection{The Conceptual Background of SDMs or What Is a Niche?}

SDMs are based on the niche concept originally dating back to the beginning of the twentieth century (Grinnell 1917). Joseph Grinnell, an American zoologist (1877-1939), was presumably the first who explicitly related the distribution of an animal, the California Thrasher Toxostoma redivivum, to the predominant climatic conditions in its range. These general relations were extended and specified by British zoologist George Evelyn Hutchinson (1903-1991). In 1957, he defined the speciesspecific niche as a multidimensional hypervolume of environmental conditions which allows a species to persist (Hutchinson 1957). Hypervolumes of high dimensions are nearly impossible to imagine. A simple special case of a hypervolume would be a two-dimensional environmental surface created by certain temperature and precipitation ranges that are occupied by a species.

It is worthwhile to distinguish between the so-called Grinnellian niche, applied in most SDM studies, and the Eltonian niche (Elton 1927; named after British ecologist and zoologist Charles Elton, 1900-1991). While the Grinnellian niche class defines the niche by "scenopoetic" variables (e.g., climate, habitat parameters) (Hutchinson 1978; Soberón 2007), Eltonian niches, in contrast, include resource variables interacting with consumers (e.g., Chase and Leibold 2003; Soberón 2007). The Eltonian noise hypothesis states that Eltonian niches are of predominant importance at smaller scales, while at large scales biotic factors become less relevant (Soberón and Nakamura 2009). Ecological niches were further divided into realized and fundamental niches (e.g., Hutchinson 1957; Soberón 2007). The set of abiotic and 


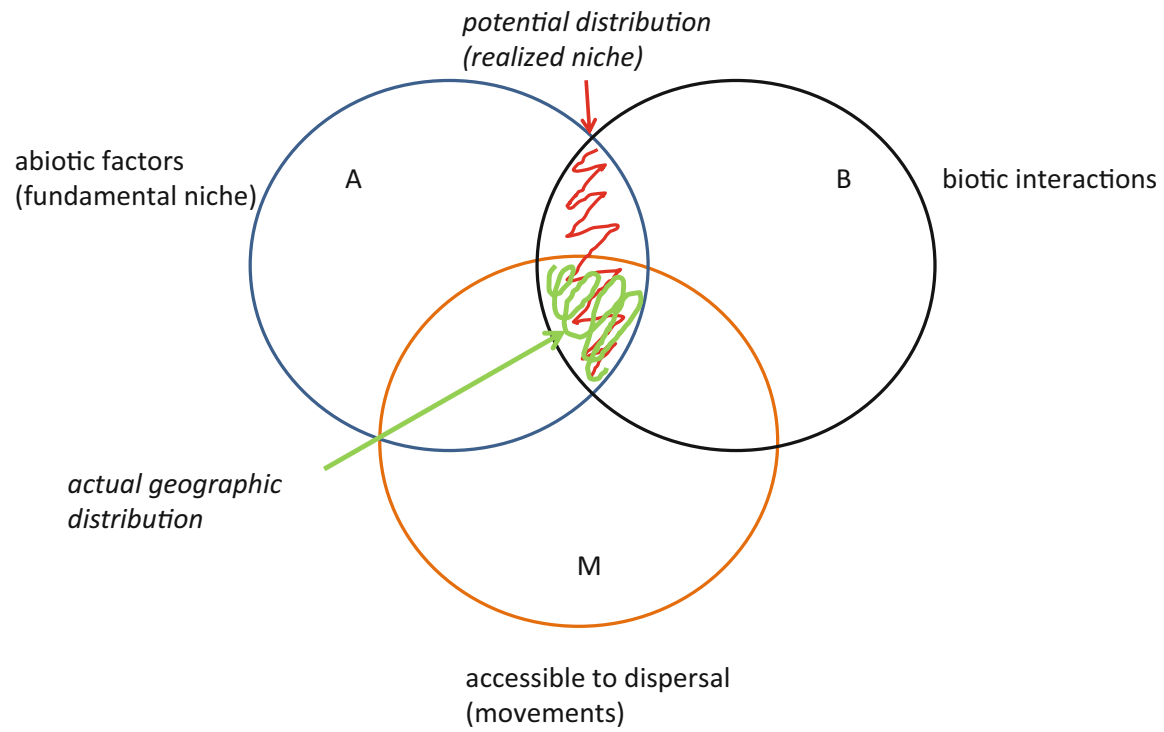

Fig. 9.1 BAM plot after Soberón and Peterson (2005). The geographic area with the right set of abiotic conditions for a species is represented by the blue circle $\mathrm{A}$ and is equivalent to the fundamental niche. Area B (black) contains a combination of interacting species. The overlapping area between $\mathrm{A}$ and $\mathrm{B}$ incorporates the potential distribution of the species, where abiotic and biotic conditions are suitable (red). The orange circle $\mathrm{M}$ represents areas where the species is able to move to. The intersection of all three circles stands for the actual geographic distribution of the species (green)

biotic conditions and resources in which an organism could survive and reproduce in the absence of competitors and other biotic interactions is called the fundamental niche. The part of the fundamental niche that is actually occupied by a species under prevailing locational factors is termed the realized niche. Interactions with other organisms such as competition, predation, or parasitism narrow the fundamental niche so that the realized niche is smaller than the niche that would be occupied without competitors. Soberón and Peterson (2005) gave a comprehensible explanation by presenting their so-called BAM plot (Fig. 9.1). Therein, the geographic distribution of a species is restricted by three main factors: (A) the abiotic conditions that allow a species to persist (this is equivalent to the fundamental niche sensu Hutchinson 1957) and (B) biotic factors, i.e., a combination of interacting species. The realized niche is an area where abiotic and biotic conditions are suitable for a species, but this is still not equal to the geographic range of a species. Some otherwise suitable areas might be simply inaccessible: $(\mathrm{M})$ is the reachable area, which could be limited by barriers and species-specific dispersal capacities. As SDMs solely rely on occurrence data, they infer information on niche characteristics only from the geographic range. Moreover, in the case of invasive species, dispersal barriers are broken down by humans. 


\subsection{How to Build a Species Distribution Model?}

In general, all correlative SDMs rely on similar approaches and require a similar set of prerequisites (Fig. 9.2): (1) Data on the distribution of a species, i.e., preferably exact locations of species' occurrences, (2) predictor variables (layers of climate or land cover data in a geographic information system, GIS) which geographically cover the selected background, and (3) appropriate algorithm(s) which relate occurrences to environmental data. In most cases, the output is a map showing areas of different suitability for the occurrence of the species. If desired, it can be transformed into a presence-absence map of the species' potential distribution by the use of thresholds (Liu et al. 2005, 2013). While general requirements for an SDM are straightforward, many practical and conceptual challenges are beyond the scope of this overview (e.g., Araújo and Guisan 2006; Heikkinen et al. 2006; Jiménez-Valverde et al. 2008).

SDMs as discussed herein differ from mechanistic models, which use the physiology of a species to quantify its niche. While we underline the fascinating potential of these studies, their applications are beyond the scope of this manuscript (but see, e.g., Khaliq et al. 2015; La Sorte and Jetz 2010).

\subsubsection{Occurrence Data}

Range maps are available for nearly every bird species (del Hoyo et al. 1992-2013, http://datazone.birdlife.org/home). However, polygons need to be transferred into occurrences with an appropriate resolution (e.g., Echarri et al. 2009; Schidelko et al. 2011). More exact occurrences are available through online databases like the Global Biodiversity Information Facility (GBIF, www.gbif.org) and mostly originate from museum specimens as well as citizen science data like those collected by birdwatchers, e.g., via eBird (www.ebird.org), underlining the tremendous importance of such data collections (Newbold 2010; Pyke and Ehrlich 2010). In addition, occurrence data come from tracking devices, which were only recently discovered as a data source for SDM studies (Jiguet et al. 2010; Quillfeldt et al. 2017). Most occurrence data show some kind of observer bias, e.g., specimens were collected along roads, close to settlements, or with different intensity across habitats or political territories (Araújo and Guisan 2006). Hence, data processing and filtering is pivotal in order to gain a reliable data source in every modeling approach (Boria et al. 2014; Ranc et al. 2017; Varela et al. 2014). However, even a limited number of data points might result in reasonable outputs (Pearson et al. 2007). 
a)

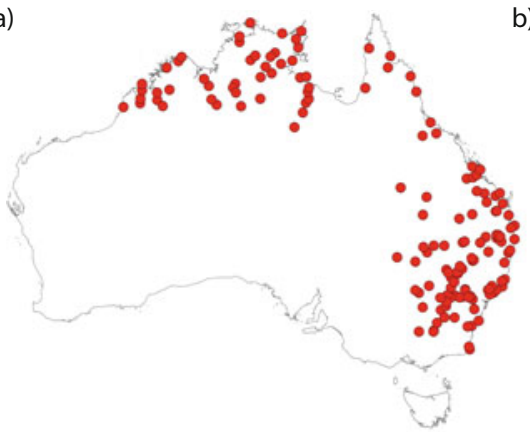

species occurrence data

)

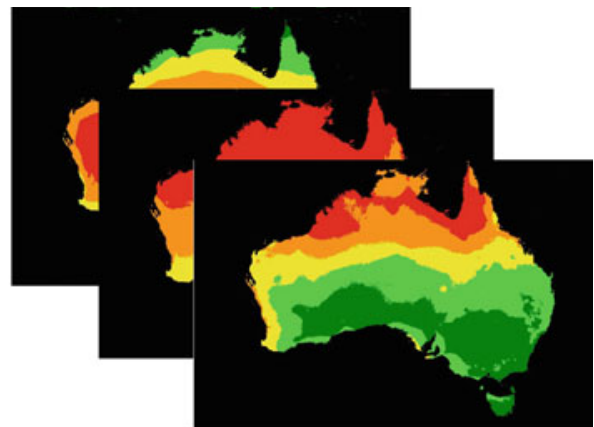

environmental data

c)
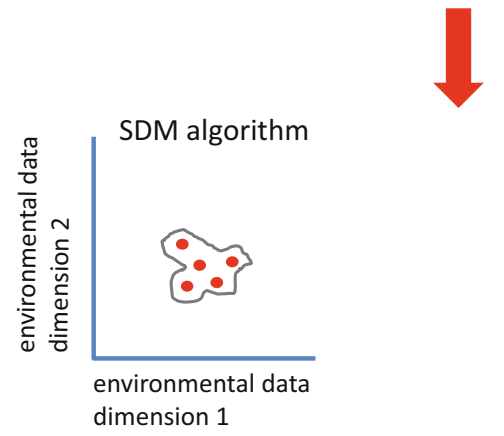

d)

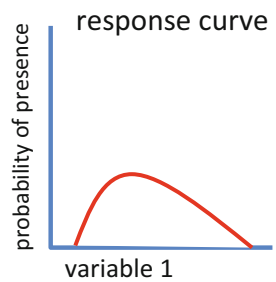

e)

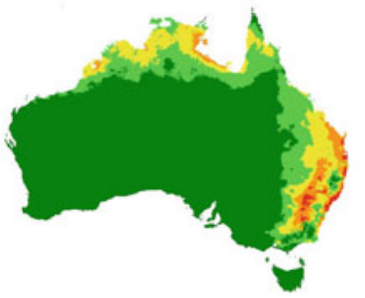

final model

Fig. 9.2 Procedure of building a species distribution model: (a) species occurrence records are (b) combined with predictor variables (e.g., climate data like temperature or precipitation), (c) an appropriate modeling algorithm is selected, and (d) the model is fitted to the data. (e) Finally, the models' predictions are mapped onto geographical space. The model can also be projected beyond the training area onto other areas or time frames. By application of thresholds, the suitability map can be transformed into a binary presence-absence map of potential distribution 


\subsubsection{Predictor Variables}

Like every model, SDMs are dependent on available predictor variables. Typical predictors are climate data like precipitation, temperature, or humidity. Climate possibly limits distributions at larger scales (Pearson and Dawson 2003). For example, the widely used 19 global BIOCLIM variables (Hijmans et al. 2005, www. worldclim.org) even include data sets for the future (under different climate change scenarios) and the past (e.g., for the last glacial maximum) which allows for hind- and forecasting of potential distributions (Huntley et al. 2007; Jetz et al. 2007; NoguésBravo 2009). In addition, remotely sensed land cover data can add a great deal of information. Nevertheless, the use of climate or land cover data has been intensively discussed (e.g., Thuiller et al. 2004). Data for the marine environment make SDMs for seabirds feasible (Engler et al. 2017). Predictor variables can highly influence model output and should be biologically meaningful (Engler et al. 2014; Rödder et al. 2009). Statistically highly correlated predictors should also be avoided as this can potentially tamper results (Heikkinen et al. 2006). Moreover, an appropriate background has to be selected (Phillips et al. 2009; Barve et al. 2011), and the incorporation of biotic factors can be considered (Anderson 2017; Heikkinen et al. 2007).

\subsubsection{Algorithms}

Long before SDMs were developed, scientists correlated species distributions with environmental factors (Grinnell 1917; Voous 1960). However, typical SDMs require computational power and were first established during the 1980s, e.g., with the creation of the software BIOCLIM (Booth et al. 2014). Subsequently, other algorithms and/or software packages like DOMAIN (Carpenter et al. 1993) and GARP (Stockwell and Peters 1999; Pereira 2002) followed. However, the breakthrough of SDMs in ecological and evolutionary research is closely tight to the publication of Maxent (Phillips et al. 2004, 2006, 2017), a machine learning algorithm with an easyto-use graphical user interface that has regularly outperformed other applications (Elith et al. 2006; Heikkinen et al. 2006, but see below). While Maxent is a single modeling approach, one widespread alternative is based on a different assumption: BIOMOD (Thuiller 2003; Thuiller et al. 2009) and its successor (biomod2, Thuiller et al. 2016) build so-called ensemble models (Araújo and New 2007). Rather than relying on one single best model, outputs of different algorithms are summarized. The basic principle is that the potential weakness of single algorithms is outweighed by the model power of the majority of algorithms.

There is no consensus which modeling approach is superior, and this may almost certainly also depend on external preconditions (Aguirre-Gutiérrez et al. 2013; Araújo and New 2007; Elith and Graham 2009; Marmion et al. 2009; Qiao et al. 2015; Shabani et al. 2016; Zhu and Peterson 2017). There are different statistics to assess the quality of SDMs like AUC (area under the curve) or TSS (true skill statistic) 
among others, but it should be noted that their explanatory powers are limited (Lobo et al. 2008; Peterson et al. 2008). Despite great methodological and conceptual progress, SDMs remain a challenging field (e.g., Araújo and Guisan 2006).

\subsubsection{Niche Comparisons}

Ecological niches of different species or populations can be compared in geographical space based on model outputs. One straightforward approach is to project models from one species onto the range of another and to quantify its predictive power. Model comparisons can be based on statistics like Schoener's $D$ inferred from model outputs and now implemented in software packages like ENMTools (Warren et al. 2010) or the approach by Broennimann et al. (2012). The so-called hypervolume algorithm directly compares $n$-dimensional environmental niche hypervolumes (Blonder et al. 2014, but see Qiao et al. 2017).

\subsection{Niche Conservatism}

One of the basic principles in evolution and ecology-niche conservatism-states that species retain their fundamental niche over time (Ricklefs and Latham 1992; Webb et al. 2002; Wiens and Graham 2005; Wiens et al. 2010). Moreover, given that ecological niches are more similar to each other than can be expected based on the phylogenetic relationships of the species, the term "phylogenetic niche conservatism" has been suggested (Losos 2008a). A vivid debate has risen about the biological meaning of niche conservatism as pattern or process (Losos 2008a, b, 2011; Wiens and Graham 2005; Wiens 2008; Pyron et al. 2015). However, it is widely accepted now that niche conservatism can be considered in the light of many different aspects rather than as a phenomenon per se. There are many obvious examples for niche conservatism in birds, e.g., the recent genomic studies that claim that many waterbirds are indeed closely related (Jarvis et al. 2014; Prum et al. 2015). In addition, feeding niches seem to be more conservative than climatic niches (Anciães and Peterson 2009; Pearman et al. 2014). Evidence for (or against) niche conservatism can be arranged along a time axis ranging from years or decades to millions of years (Peterson 2011; Engler et al. 2017). In this regard, the most recent events are species invasions, in which niches change or remain conservative during the invasion process (Guisan et al. 2014; Broennimann et al. 2007; Peterson 2011). In contrast, the analysis of speciation events, e.g., by comparing species pairs or phylogenies of closely related taxa, is usually related to much longer time periods. Herein, we will follow this temporal structure by having a closer look at avian invasions and review some aspects of niche evolution tied to speciation events. 


\subsection{Evaluating Avian Invasions}

International trading and human transport have pushed the global spread of non-native species (Mack et al. 2000). While they are often discussed in terms of negative impacts, on a global scale, the impact of non-native birds is generally assumed to be small (Blackburn et al. 2009: Chap. 7.5 and references therein). Nevertheless, among invasive species, birds belong to the most ubiquitous and conspicuous non-native animals. Typical examples are Common Starlings Sturnus vulgaris in North America and Western European countryside birds in New Zealand or Common Mynas Acridotheres tristis from South and Southeast Asia, which are now distributed in various areas of the world.

Globally, about 420 bird species have established populations outside their indigenous range due to human transportation and subsequent deliberate or unintended release (Dyer et al. 2017). Hence, it is very surprising that there is only a very limited amount of SDM studies on invasive birds. In a recent systematic overview, Engler et al. (2017) found 27 studies dealing with SDMs of non-native birds. These studies only covered less than $10 \%$ of the species with non-native populations worldwide. There is also a strong bias in the geographic scope of SDM studies, as they mainly focus on few well-known non-native birds brought to Western Palearctic and Nearctic regions (Engler et al. 2017). In some parts of the world, intentional release was particularly important in the spread of non-native species. For example, in New Zealand so-called acclimatization societies propagated and conducted the introduction of British farmland birds, and in parts of Asia, birds are released for religious ceremonies (Blackburn et al. 2009; Severinghaus and Chi 1999; Sodhi et al. 2011). Engler et al. (2017) also found a taxonomic bias in published SDM studies. Only 11 families are represented, with ducks, geese, and swans (Anatidae); pheasants and allies (Phasianidae); waxbills, munias, and allies (Estrildidae); and African and New World parrots (Psittacidae) being particular prevalent among them. As a single prominent species, there are in-depth studies on Rose-ringed Parakeets Psittacula krameri, perhaps one of the most successful avian non-native species in Europe (Strubbe and Matthysen 2009).

The biological invasion of a non-native species is a multistage process. The so-called invasion pathway starts with a native species, which after transport, introduction, establishment, and spread becomes an invasive species or sometimes even a pest (Duncan et al. 2003; Sol et al. 2005; Blackburn et al. 2009; see Bauer and Woog 2011 for discussion on terms). While the success of invasive species depends on different factors, a predominant role of the pure number of individuals has become widely accepted (e.g., Blackburn et al. 2015 and references therein, but see Moulton et al. 2011, 2012a, b, 2013).

Biological invasions can be regarded as natural experiments and help to understand how species colonize new environments (e.g., Guisan et al. 2014; Sax et al. 2007 and dating back to Elton 1958). Over the last years, studies using SDMs have greatly contributed to the field of invasion biology, e.g., by identifying potential risk areas for invasions (Peterson and Viglais 2001). SDMs can also contribute to 
comprehensive studies of niche evolution (Guisan et al. 2014). The question in focus is whether non-native species retain their niche or whether they change it during the invasion process. Knowledge about niche shifts may also help to select appropriate models, e.g., based on all available records or only those from the native or non-native area, respectively (Broennimann and Guisan 2008; Peterson and Viglais 2001; Mau-Crimmins et al. 2006). Improved model predictions can subsequently lead to better assessments of current or future risk areas, although this target has only been rarely addressed for birds (Stiels et al. 2011).

Niche shifts between native and non-native ranges can also point to evolutionary processes during the invasion. In contrast, habitat or climate matching indicates niche conservatism. However, niche comparisons are a great challenge in non-native species (Elith et al. 2010). Invasive populations typically start their spread from a limited number of locations. Hence, there often was simply not enough time to reach equilibrium with the environment and to "fill" the niche. In this case, the niche occupied in the non-native range only represents a subset of the conditions found in the native range (e.g., Engler et al. 2017; Stiels et al. 2011). Guisan et al. (2014) classify niche changes into unfilling, stability, and expansion situations and stress the importance of accounting for available climatic conditions and climatic analogy. Hence, dissimilarity does not automatically point to evolutionary changes in the fundamental niche.

One of the few multispecies studies shows that niche conservatism is the dominant phenomenon observed among 28 non-native species in Europe (Strubbe et al. 2013). Therein, climatic niches between native and non-native ranges differ, but the non-native range can be regarded a subset of the native range instead of a shift outside the native niche space. Nevertheless, results may differ among species and might require species-specific approaches as highlighted for estrildid finches (Stiels et al. 2015). Intraspecific variation and subsequent genetic drift during the invasion process or interspecific interactions may allow species to expand their niche in the non-native range. For example, a species might extend its habitat preferences or its climate niche toward colder temperatures as shown for Alexandrine Parakeets Psittacula eupatria (Ancillotto et al. 2015). The great potential of SDM applications in the study of non-native birds is still not fully exploited, and further studies might easily explore neglected taxa or areas hitherto less in focus.

\subsection{Speciation and Niche Evolution}

Speciation and geographical distributions are closely tight. Since Ernst Mayr's epoch-making work (Mayr 1942), allopatric speciation has emerged as a fundamental evolutionary process which is closely linked to climate niche evolution (e.g., Wiens 2004; Hua and Wiens 2013). Hence, "niche conservatism as an emerging principle" (Wiens et al. 2010) is in focus of recent studies on speciation and phylogeography (see paragraph "niche conservatism" and Engler et al. 2017 for a current avian review). As already described for non-native species, SDMs of two or 
more different taxa of a clade can be analyzed in order to compare similarities and changes. The integration of phylogenetic analyses into recently developed statistical tools facilitates analyses of evolutionary changes in environmental niches. This even includes the reconstruction of so-called ancestral niches, i.e., the reconstructed niche space once potentially occupied by a common ancestor of recent taxa (e.g., Cooper et al. 2010; Evans et al. 2009; Graham et al. 2004b; Heibl and Calenge 2013; Revell 2012; Rödder et al. 2013). While methodological details are beyond the focus of this article, we stress their great potential for future avian evolutionary studies (Engler et al. 2017, see Gómez et al. 2016 for a recent avian example). We simultaneously call for very cautious interpretations, as similar diversification patterns can be caused by completely different processes (Warren et al. 2014).

A highly influential study on avian niche conservatism analyzed climatic niches of sister species: Peterson et al. (1999) conducted SDMs of allopatrically distributed sister species along a faunal divide - the Isthmus of Tehuantepec in Mexico. The basic assumption of their approach is that, if two taxa show conserved niches, SDMs of one species should be able to predict the distribution of the other and vice versa. Their prediction was confirmed, and their results point to a general pattern of conserved niches. Similar methods can also be transferred to intraspecific populations like non-native species (see above) or subspecies (Peterson and Holt 2003). However, their results were not as homogeneous as for the analyses of sister species, and predictive power varied among studied taxa. SDMs also offer opportunities for the study of sister species with overlapping ranges and hybrid zones like those of two European Hippolais warblers (Engler et al. 2013).

While these examples refer to current distributional patterns, SDMs also allow for a closer look at the influence of historical events on present patterns like range contractions to refugial areas. Hence, paleodistribution models can greatly help to understand current diversity and its underlying evolutionary processes (NoguésBravo 2009). For instance, the North American Painted Bunting Passerina ciris shows a disjunct breeding range. Shipley et al. (2013) conducted current SDMs as well as paleodistribution models in order to test whether the distributional gap is of bioclimatic origin. As current SDMs showed suitable climatic conditions in this gap, this hypothesis was refused, while a relation to migratory constraints that connect breeding and wintering ranges was preferred. In addition, this explanation can be associated with past distributions as inferred from hindcasting, given that the species might follow past expansion paths after being restricted to southerly areas during the Pleistocene (see also Ruegg et al. 2006). Another example stems from the Neotropics. An analysis of potential Pleistocene refugial areas for members of the thrush-like Schiffornis complex revealed broad congruence with current phylogroups identified by molecular methods (Peterson and Nyári 2007). Recently, SDMs were also applied to test the ring-species concept in Greenish Warblers Phylloscopus trochiloides (Peterson and Anamza 2017). The range of this species forms a ring around the Tibetan plateau, but the existence of Pleistocene refugia revealed by paleodistribution models questions the validity of the ring-species concept (Peterson and Anamza 2017). Hypotheses on former refugia can also be addressed by multispecies approach. Stacked SDMs of many estrildid finch species were used to test refugial hypotheses 
for forest and savanna species in Africa and Australia (Schidelko et al. 2011, 2013). They revealed a pattern of relative stability of biodiversity hotspots but also point to the importance of current shelf zones as historical retreat areas.

Many of the aforementioned examples mainly relied on single species or species pairs; however, applications of SDMs are equally transferable to multispecies phylogenies. The question, whether climatic niches are conservative, was intensively studied in North and Central American jays of the genus Aphelocoma (Rice et al. 2003; McCormack et al. 2009). These studies are particular informative, because originally a strong deviation from niche conservatism was found (Rice et al. 2003). This was rejected later, mainly based on recent sophisticated statistical approaches like the use of null models (McCormack et al. 2009). While we restrict our overview to moderate time scales up to the genus level, it is well worth noting that in some studies longer time scales were taken into account and analyses up to the family level were conducted (reviewed by Engler et al. 2017). Examples of analyzed genera also include the Asiatic genus Pomatorhinus, for which results about niche conservatism not only differ for different subclades but also for different predictor variables (Nyári and Reddy 2013).

The migratory behavior of many birds makes it possible to look at so-called seasonal niches (Joseph 1996; Joseph and Stockwell 2000; Martínez-Meyer et al. 2004; Engler et al. 2017). Birds are exposed to different environmental conditions during and outside the breeding season, often combined with a different distribution-the breeding and the wintering range. Hence, it is not only possible to analyze, whether niches remain stable throughout the year, but also to ask, whether realized breeding and wintering niches might evolve differently in a clade over evolutionary time scales (Gómez et al. 2016; Martínez-Meyer et al. 2004; Laube et al. 2015).

\subsection{Assisting Taxonomy}

Newly described taxa are often only known from a handful of locations, and SDMs can help to gain information about their potential range and its environmental correlates. Moreover, even taxonomic implications might be supported from SDMs as mainly outlined by Wiens (2004) and Wiens and Graham (2005): A newly found population, e.g., in a mountain range, might be isolated from another well-known population. SDMs are able to reveal whether the intervening habitat (e.g., lowland areas with a different vegetation type and climate) might represent a potential barrier to gene flow (Wiens and Graham 2005). If SDMs show a corridor of suitable habitat between both areas, then gene flow is more likely, and genetic discreteness of the new population is questionable. Highly valuable interpretations can also be inferred from direct comparisons of niches between both populations (see Niche Comparisons above). If the ecological niche of the new population is not a subset of the well-known population, this can point to evolutionary changes that happened in the past (and subsequently conservative niches that prevented further spread) (Wiens and Graham 2005). One avian case study analyzed a disjunct population of a hummingbird, the Blossomcrown Anthocephala floriceps in 
Colombia, where the population from the Sierra de Santa Marta is disjunct from the Andean population. Both live under different climatic conditions as cross-projections of population-specific SDMs show (Lozana-Jaramillo et al. 2014). In addition, SDMs were applied for recently described taxa; a prominent example is different members of the Neotropical tapaculos (Rhinocryptidae) (Avendaño and Donagan 2015; Avendaño et al. 2015; Nemésio et al. 2013).

In a nutshell, SDMs offer the potential to become a central part in integrative taxonomic studies. They already tremendously contributed to invasion biology, phylogeography, and research related to climatic niche evolution. In combination with recent methodological advances and an increasing knowledge about avian systematics and genomics, they will likely play an important role in further ornithological studies (Engler et al. 2017).

\section{References}

Aguirre-Gutiérrez J, Carvalheiro LG, Polce C, van Loon EE, Raes N, Reemer M, Biesmeijer JC (2013) Fit for purpose: species distribution model performance depends on evaluation criteria Dutch hoverflies as a case study. PLoS One 8(3):e63708. https://doi.org/10.1371/journal.pone. 0063708

Anciães M, Peterson AT (2009) Ecological niches and their evolution among Neotropical manakins (Aves: Pipridae). J Avian Biol 40:591-605

Ancillotto L, Strubbe D, Menchetti M, Mori E (2015) An overlooked invader? Ecological niche, invasion success and range dynamics of the Alexandrine parakeet in the invaded range. Biol Invasions 18(2):583-595. https://doi.org/10.1007/s10530-015-1032-y

Anderson RP (2017) When and how should biotic interactions be considered in models of species niches and distributions. J Biogeogr 44:8-17

Araújo MB, Guisan A (2006) Five (or so) challenges for species distribution modelling. J Biogeogr 33:1677-1688

Araújo MB, New M (2007) Ensemble forecasting of species distributions. Trends Ecol Evol 22:42-47

Avendaño JE, Donagan TM (2015) A distinctive new subspecies of Scytalopus griseicollis (Aves, Passeriformes, Rhinocryptidae) from the northern Eastern Cordillera of Colombia and Venezuela. ZooKeys 506:137-153

Avendaño JE, Cuervo AM, López-O JPm Gutiérrez-Pinto N, Cortés-Diago A, Cadena CD (2015) A new species of tapaculo (Rhinocryptidae: Scytalopus) from the Serranía de Perijá of Colombia and Venezuela. Auk 132:450-466

Barve N, Barve V, Jiménez-Valverde A, Lira-Noriega A, Maher SP, Peterson AT, Soberón J, Villalobos F (2011) The crucial role of the accessible area in ecological niche modelling and species distribution modelling. Ecol Model 222:1810-1819

Bauer H-G, Woog F (2011) On the 'invasiveness' of non-native bird species. IBIS 153:204-206

Blackburn TM, Lockwood JL, Cassey P (2009) Avian invasions. The ecology and evolution of exotic birds. Oxford University Press, Oxford, New York

Blackburn TM, Lockwood JL, Cassey P (2015) The influence of numbers on invasion success. Mol Ecol 24:1942-1953

Blonder B, Lamanna C, Violle C, Enquist BJ (2014) The n-dimensional hypervolume. Glob Ecol Biogeogr 23:595-609 
Booth TH, Nix HA, Busby JR, Hutchinson MF (2014) BIOCLIM: the first species distribution modelling package, its early applications and relevance to most current MAXENT studies. Divers Distrib 20:1-9

Boria RA, Olson LE, Goodman SM, Anderson RP (2014) Spatial filtering to reduce sampling bias can improve the performance of ecological niche models. Ecol Model 275:73-77

Broennimann O, Guisan A (2008) Predicting current and future biological invasions: both native and invaded ranges matter. Biol Lett 4:585-589

Broennimann O, Treier UA, Müller-Schärer H, Thuiller W, Peterson AT, Guisan A (2007) Evidence of climatic niche shift during biological invasion. Ecol Lett 10:701-709

Broennimann O, Fitzpatrick MC, Pearman PB, Petitpierre B, Pellissier L, Yoccoz NG, Thuiller W, Fortin M-J, Randin C, Zimmermann NE, Graham CH, Guisan A (2012) Measuring ecological niche overlap from occurrence and spatial environmental data. Glob Ecol Biogeogr 21:481-497

Carpenter G, Gillison AN, Winter J (1993) DOMAIN: a flexible modelling procedure for mapping potential distributions of plants and animals. Biodivers Conserv 2:667-680

Chase J, Leibold M (2003) Ecological niches: linking classical and contemporary approaches. University of Chicago Press, Chicago

Cooper N, Jetz W, Freckleton RP (2010) Phylogenetic comparative approaches for studying niche conservatism. J Evol Biol 23:2529-2539

del Hoyo J, Elliott A, Sargatal J (eds) (1992-2013) Handbook of the birds of the world, 16 vol and special volume. Lynx Edicions, Barcelona

Duncan RP, Blackburn TM, Sol D (2003) The ecology of bird introductions. Annu Rev Ecol Evol Syst 34:71-98

Dyer EE, Cassey P, Redding DW, Collen B, Franks V, Gaston KJ, Jones KE, Kark S, Orme CDL, Blackburn TM (2017) The global distribution and drivers of alien bird species richness. PLoS Biol 15(1):e2000942. https://doi.org/10.1371/journal.pbio.2000942

Echarri F, Tambussi C, Hospitaleche CA (2009) Predicting the distribution of the crested tinamous, Eudromia spp. (Aves, Tinamiformes). J Ornithol 150:75-84

Elith J, Graham CH (2009) Do they? How do they? WHY do they differ? On finding reasons for differing performances of species distribution models. Ecography 32:66-77

Elith J, Leathwick JR (2009) Species distribution models: ecological explanation and prediction across space and time. Annu Rev Ecol Evol Syst 40:677-697

Elith J, Graham CH, Anderson RP, Dudik M, Ferrier S, Guisan A, Hijmans RJ, Huettmann F, Leathwick JR, Lehmann A, Li J, Lohmann LG, Loiselle BA, Manion G, Moritz C, Nakamura M, Nakazawa Y, Overton JMM, Peterson AT, Phillips SJ, Richardson K, Scachetti-Pereira R, Schapire RE, Soberón J, Williams S, Wisz MS, Zimmermann NE (2006) Novel methods improve prediction of species' distributions from occurrence data. Ecography 29:129-151

Elith J, Kearney M, Phillips S (2010) The art of modelling range-shifting species. Methods Ecol Evol 1:330-342

Elton CS (1927) Animal ecology. Sidgwick and Jackson, London

Elton CS (1958) The ecology of invasions by animals and plants. Springer, Boston

Engler JO, Rödder D, Elle O, Hochkirch A, Secondi J (2013) Species distribution models contribute to determine the effect of climate and interspecific interactions in moving hybrid zones. J Evol Biol 26:2487-2496

Engler JO, Rödder D, Stiels D, Förschler MI (2014) Suitable, reachable but not colonised: seasonal niche duality in an endemic mountainous songbird. J Ornithol 155:657-669

Engler JO, Stiels D, Schidelko K, Strubbe D, Quillfeldt P, Brambilla M (2017) Avian SDMs: current state, challenges, and opportunities. J Avian Biol. https://doi.org/10.1111/jav.01248

Evans MEK, Smith SA, Flynn RS, Donoghue MJ (2009) Climate, niche evolution, and diversification of the "bird-cage" evening primroses (Oenothera, sections Anogra and Kleinia). Am Nat $173: 225-240$ 
Gómez C, Tenorio EA, Montoya P, Cadena CD (2016) Niche-tracking migrants and niche-switching residents: evolution of climatic niches in New World warblers (Parulidae). Proc R Soc B 283:20152458

Graham CH, Ferrier S, Huettmann F, Moritz C, Peterson AT (2004a) New developments in museum-based informatics and applications in biodiversity analysis. Trends Ecol Evol 19:497-503

Graham CH, Ron SR, Santos JC, Schneider CJ, Moritz C (2004b) Integrating phylogenetics and environmental niche models to explore speciation mechanisms in dendrobatid frogs. Evolution 58:1781-1793

Grinnell J (1917) The niche-relationships of the California thrasher. Auk 34:427-433

Guisan A, Thuiller W (2005) Predicting species distribution: offering more than simple habitat models. Ecol Lett 8:993-1009

Guisan A, Tingley R, Baumgartner JB, Naujokaitis-Lewis I, Sutcliffe PR, Tulloch AIT, Regan TJ, Brotons L, McDonald-Madden E, Mantyka-Pringle C, Martin TG, Rhodes JR, Maggini R, Setterfield SA, Elith J, Schwartz MW, Wintle BA, Broennimann O, Austin M, Ferrier S, Kearney MR, Possingham HP, Buckley YM (2013) Predicting species distributions for conservation decisions. Ecol Lett 16:1424-1435

Guisan A, Petitpierre B, Broennimann O, Daehler C, Kueffer C (2014) Unifying niche shift studies: insights from biological invasions. Trends Ecol Evol 29:260-269

Heibl C, Calenge C (2013) PHYLocLim: integrating phylogenetics and climatic niche modelling. Available from https://cran.r-project.org/web/packages/phyloclim/index.html

Heikkinen RK, Luoto M, Araújo MB, Virkkala R, Thuiller W, Sykes MT (2006) Methods and uncertainties in bioclimatic envelope modelling under climate change. Prog Phys Geogr 30:751-777

Heikkinen RK, Luoto M, Virkkala R, Pearson RG, Körber J-H (2007) Biotic interactions improve prediction of boreal bird distributions at macro-scales. Gobal Ecol Biogeogr 16:754-763

Hijmans RJ, Cameron SE, Parra JL, Jones PG, Jarvis A (2005) Very high resolution interpolated climate surfaces for global land areas. Int J Climatol 25:1965-1978

Hua X, Wiens JJ (2013) How does climate influence speciation. Am Nat 182:1-12. https://doi.org/ $10.1086 / 670690$

Huntley B, Green RE, Collingham YC, Willis SG (2007) A climatic atlas of European breeding birds. Lynx Edicions, Barcelona

Hutchinson GE (1957) Concluding remarks. Cold Spring Harb Symp Quant Biol 22:415-427

Hutchinson GE (1978) An introduction to population biology. Yale University Press, New Haven, CT

Jarvis ED et al (2014) Whole-genome analyses resolve early branches in the tree of life of modern birds. Science 346:1320-1331

Jeschke JM, Strayer DL (2008) Usefulness of bioclimatic models for studying climate change and invasive species. Ann N Y Acad Sci 1134:1-24

Jetz W, Wilcove DS, Dobson AP (2007) Projected impacts of climate and land-use change on global diversity of birds. PLoS Biol 5:e157. https://doi.org/10.1371/journal.pbio.0050157

Jiguet F, Barbet-Massin M, Chevallier D (2010) Predictive distribution models applied to satellite tracks: modelling the western African winter range of European migrant Black Storks Ciconia nigra. J Ornithol 152:111-118

Jiménez-Valverde A, Lobo JM, Hortal J (2008) Not as good as they seem: the importance of concepts in species distribution modelling. Divers Distrib 14:885-890

Joseph L (1996) Preliminary climatic overview of migration patterns in South American Austral migrant passerines. Ecotropica 2:185-193

Joseph L, Stockwell D (2000) Temperature-based models of the migration of Swainson's Flycatcher (Myiarchus swainsoni) across South America: a new use for museum specimens of migratory birds. Proc Acad Natl Sci Phila 150:293-300 
Khaliq I, Fritz SA, Prinzinger R, Pfenninger M, Böhning-Gaese K, Hof C (2015) Global variation in thermal physiology of birds and mammals: evidence for phylogenetic niche conservatism only in the tropics. J Biogeogr 42:2187-2196

La Sorte FA, Jetz W (2010) Avian distributions under climate change: towards improved projections. J Exp Biol 213:862-869

Laube I, Graham CH, Böhning-Gaese K (2015) Niche availability in space and time: migration in Sylvia warblers. J Biogeogr 42:1896-1906

Liu C, Berry PM, Dawson TP, Pearson RG (2005) Selecting thresholds of occurrence in the prediction of species distributions. Ecography 28:385-393

Liu C, White M, Newell G (2013) Selecting thresholds for the prediction of species occurrence with presence-only data. J Biogeogr 40:778-789

Lobo JM, Jiménez-Valverde A, Real R (2008) AUC: a misleading measure of the performance of predictive distribution models. Glob Ecol Biogeogr 17:145-151

Losos JB (2008a) Phylogenetic niche conservatism, phylogenetic signal and the relationship between phylogenetic relatedness and ecological similarity among species. Ecol Lett 11:995-1007

Losos JB (2008b) Rejoinder to Wiens (2008): phylogenetic niche conservatism, its occurrence and importance. Ecol Lett 11:1005-1007

Losos JB (2011) Seeing the forest for the trees: the limitations of phylogenies in comparative biology. Am Nat 177:709-727

Lozana-Jaramillo M, Rico-Guevara A, Cadena CD (2014) Genetic differentiation, niche divergence, and the origin and maintenance of the disjunct distribution in the Blossomcrown Anthocephala floriceps (Trochilidae). PLoS One 9(9):e108345. https://doi.org/10.1371/journal.pone.0108345

Mack RN, Simberloff D, Lonsdale WM, Evans H, Clout M, Bazzaz FA (2000) Biotic invasions: causes, epidemiology, global consequences, and control. Ecol Appl 10:689-710

Marmion M, Parviainen M, Luoto M, Heikkinen RK, Thuiller W (2009) Evaluation of consensus methods in predictive species distribution modelling. Divers Distrib 15:59-69

Martínez-Meyer E, Peterson AT, Navarro-Sigüenza A (2004) Evolution of seasonal ecological niches in the Passerina buntings (Aves: Cardinalidae). Proc R Soc B 271:1151-1157

Mau-Crimmins TM, Schussmann HR, Geiger EL (2006) Can the invaded range of a species be predicted using only native-range data? Lehmann lovegrass (Eragrostis lehmanniana) in the southwestern United States. Ecol Model 193:736-746

Mayr E (1942) Systematics and the origin of species. Columbia University Press, New York

McCormack JE, Zellmer AJ, Knowles LL (2009) Does niche divergence accompany allopatric divergence in Aphelocoma jays as predicted under ecological speciation? Insights from tests with niche models. Evolution 64:1231-1244

Moulton MP, Cropper WP Jr, Avery ML (2011) A reassessment of the role of propagule pressure in influencing fates of passerine introductions to New Zealand. Biodivers Conserv 20:605-623

Moulton MP, Cropper WP Jr, Moulton LE, Avery ML, Peacock D (2012a) A reassessment of historical records of avian introductions to Australia: no case for propagule pressure. Biodivers Conserv 21:155-174

Moulton MP, Cropper WP Jr, Avery ML (2012b) Historical records of passerine introductions to New Zealand fail to support the propagule pressure hypothesis. Biodivers Conserv 21:297-307

Moulton MP, Cropper WP Jr, Avery ML (2013) Is propagule size the critical factor in predicting introductions outcomes in passeriform birds? Biol Invasions 15:1449-1458

Nemésio A, Rasmussen C, Aguiar AP, Pombal JP Jr, Dubois A (2013) Nomenclatural issues in ornithology: the incredible controversy on the identity of a long overlooked Brazilian bird. Zootaxa 3734:241-258

Newbold T (2010) Applications and limitations of museum data for conservation and ecology, with particular attention to species distribution models. Prog Phys Geogr 34:3-22

Nogués-Bravo D (2009) Predicting the past distribution of species climatic niches. Glob Ecol Biogeogr 18:521-531 
Nyári ÁS, Reddy S (2013) Comparative phyloclimatic analysis and evolution of ecological niches in the scimitar babblers (Aves: Timaliidae: Pomatorhinus). PLoS One 8(2):e55629. https://doi. org/10.1371/journal.pone.0055629

Pearman PB, Guisan A, Broennimann O, Randin CF (2007) Niche dynamics in space and time. Trends Ecol Evol 23:149-158

Pearman PB, Lavergne S, Roquet C, Wüest R, Zimmermann NE, Thuiller W (2014) Phylogenetic patterns of climatic, habitat and trophic niches in a European avian assemblage. Glob Ecol Biogeogr 23:414-424

Pearson RG, Dawson TP (2003) Predicting the impacts of climate change on the distribution of species: are bioclimate envelope models useful? Glob Ecol Biogeogr 12:361-371

Pearson RG, Raxworthy CJ, Nakamura M, Peterson AT (2007) Predicting species distributions from small numbers of occurrence records: a test case using cryptic geckos in Madagascar. J Biogeogr 34:102-117

Pereira RS (2002) Desktop GARP. Kansas: University of Kansas Center for Research. Available from http://www.nhm.ku.edu/desktopgarp/index.html

Peterson AT (2011) Ecological niche conservatism: a time-structured review of evidence. J Biogeogr 38:817-827

Peterson AT, Anamza T (2017) Reexamining Phylloscopus trochiloides as a ring species: a refugial counter hypothesis. J Avian Biol 48(12):1608-1613. https://doi.org/10.1111/jav.01167

Peterson AT, Holt RD (2003) Niche differentiation in Mexican birds: using point occurrences to detect ecological innovation. Ecol Lett 6:774-782

Peterson AT, Nyári ÁS (2007) Ecological niche conservatism and Pleistocene refugia in the thrush-like mourner, Schiffornis sp., in the Neotropics. Evolution 62-1:173-183

Peterson AT, Soberón J (2012) Species distribution modelling and ecological niche modelling: getting the concepts right. Natureza \& Conservação 10:102-107

Peterson TA, Viglais DA (2001) Predicting species invasions using ecological niche modeling: new approaches from bioinformatics attack a pressing problem. Bioscience 51:363-371

Peterson AT, Soberón J, Sánchez-Cordero V (1999) Conservatism of ecological niches in evolutionary time. Science 285:1265-1267

Peterson AT, Papes M, Soberón J (2008) Rethinking receiver operating characteristic analysis applications in ecologinal niche modeling. Ecol Model 213:63-72

Peterson AT, Soberón J, Pearson RG, Anderson RP, Martínez-Meyer E, Nakamura M, Araújo MB (2011) Ecological niches and geographic distributions. Princeton University Press, Princeton, Oxford

Phillips SJ, Dudík M, Schapire RE (2004) A maximum entropy approach to species distribution modeling. Proceedings of the 21st international conference on machine learning. Banff, Canada

Phillips SJ, Anderson RP, Schapire RE (2006) Maximum entropy modeling of species geographic distributions. Ecol Model 190:231-259

Phillips SJ, Dudík M, Elith J, Graham CH, Lehmann A, Leathwick J, Ferrier S (2009) Sample selection bias and presence-only distribution models: implications for background and pseudoabsence data. Ecol Appl 19:181-197

Phillips SJ, Anderson RP, Dudík M, Schapire RE, Blair ME (2017) Opening the black-box: an open-source release of Maxent. Ecography 40:887-893

Prum RO, Berv JS, Dornburg A, Field DJ, Townsend JP, Moriarty Lemmon E, Lemmon AR (2015) A comprehensive phylogeny of birds (Aves) using targeted next-generation DNA sequencing. Nature 526:569-573

Pyke GH, Ehrlich PR (2010) Biological collections and ecological/environmental research: a review, some observations and a look to the future. Biol Rev 85:247-266

Pyron RA, Costa GC, Patten MA, Burbrink FT (2015) Phylogenetic niche conservatism and the evolutionary basis of ecological speciation. Biol Rev 90:1248-1262

Qiao H, Soberón J, Peterson AT (2015) No silver bullets in correlative ecological niche modelling: insights from testing among many potential algorithms for niche estimation. Methods Ecol Evol 6:1126-1136 
Qiao H, Escobar LE, Saupe EE, Ji L, Soberón J (2017) A cautionary note on the use of hypervolume kernel density estimators in ecological niche modelling. Glob Ecol Biogeogr 26:1066-1070

Quillfeldt P, Engler JO, Silk JRD, Phillips RA (2017) Influence of device accuracy and choice of algorithm for species distribution modelling of seabirds: a case study using black-browed albatrosses. J Avian Biol 48(12):1549-1555. https://doi.org/10.1111/jav.01238

Ranc N, Santini L, Rondinini C, Boitani L, Poitevin F, Angerbjörn A, Maiorano L (2017) Performance tradeoffs in target-group bias correction for species distribution models. Ecography 40:1076-1087

Revell LJ (2012) Phytools: an R package for phylogenetic comparative biology (and other things). Methods Ecol Evol 3:217-223

Rice NH, Martínez-Meyer E, Peterson AT (2003) Ecological niche differentiation in the Aphelocoma jays: a phylogenetic perspective. Biol J Linn Soc 80:369-383

Ricklefs RE, Latham RE (1992) Intercontinental correlation of geographical ranges suggests stasis in ecological traits of relict genera of temperate perennial herbs. Am Nat 139:1305-1321

Rödder D, Schmidtlein S, Veith M, Lötters S (2009) Alien invasive Slider Turtle in unpredicted habitat: a matter of niche shift or predictors studied. PLoS One 4(11):e7843. https://doi.org/10. 1371/journal.pone.0007843

Rödder D, Lawing AM, Flecks M, Ahmadzadeh F, Dambach J, Engler JO, Habel JC, Hartmann T, Hörnes D, Ihlow F, Schidelko K, Stiels D, Polly PD (2013) Evaluating the significance of paleophylogeographic species distribution models in reconstructing quaternary range-shifts of Nearctic chelonians. PLoS One 8(10):e72855. https://doi.org/10.1371/journal.pone.0072855

Ruegg KC, Hijmans RJ, Moritz C (2006) Climate change and the origin of migratory pathways in the Swainson's thrush Catharus ustulatus. J Biogeogr 33:1172-1182

Sax DF, Stachowicz JJ, Brown JH, Bruno JF, Dawson MN, Gaines SD, Grosberg RK, Hastings A, Holt RD, Mayfield MM, O'Connor MI, Rice WR (2007) Ecological and evolutionary insights from species invasions. Trends Ecol Evol 22:465-471

Schidelko K, Stiels D, Rödder D (2011) Historical stability of diversity patterns in African estrildid finches (Aves: Estrildidae)? Biol J Linn Soc 102:455-470

Schidelko K, Wüstenhagen N, Stiels D, van den Elzen R, Rödder D (2013) Continental shelf as potential retreat areas for Austral-Asian estrildid finches (Passeriformes: Estrildidae) during the Pleistocene. J Avian Biol 44:121-132

Severinghaus LL, Chi L (1999) Prayer animal release in Taiwan. Biol Conserv 89:301-304

Shabani F, Kumar L, Ahmadi M (2016) A comparison of absolute performance of different correlative and mechanistic species distribution models in an independent area. Ecol Evol 6:5973-5986

Shipley JR, Contina A, Batbayar N, Bridge ES, Peterson AT, Kelly JF (2013) Niche conservatism and disjunct populations: a case study with painted buntings (Passerina ciris). Auk 130:476-486

Soberón J (2007) Grinnellian and Eltonian niches and geographic distributions of species. Ecol Lett $10: 1115-1123$

Soberón J, Nakamura M (2009) Niches and distributional areas: concepts, methods, and assumptions. Proc Natl Acad Sci USA 106:19644-19650

Soberón J, Peterson AT (2005) Interpretation of models of fundamental ecological niches and species' distributional areas. Biodivers Inform 2:1-10

Sodhi NS, Şekercioğlu ÇH, Barlow J, Robinson SK (2011) Conservation of tropical birds. WileyBlackwell, Oxford

Sol D, Blackburn TM, Cassey P, Duncan RP, Clavell J (2005) The ecology and impact of non-indigenous birds. In: del Hoyo J, Elliott A, Sargatal J (eds) Handbook of the birds of the world. X. Cuckoo-shrikes to thrushes. Lynx Edicions, Barcelona, pp 13-35

Stiels D, Schidelko K, Engler JO, van den Elzen R, Rödder D (2011) Predicting the potential distribution of the invasive Common Waxbill Estrilda astrild (Passeriformes: Estrildidae). J Ornithol 152:769-780

Stiels D, Gaißer B, Schidelko K, Engler JO, Rödder D (2015) Niche shift in four non-native estrildid finches and implications for species distribution models. Ibis 157:75-90 
Stockwell DRB, Peters DP (1999) The GARP modelling system: problems and solutions to automated spatial prediction. Int J Geogr Inf Syst 13:143-158

Strubbe D, Matthysen E (2009) Establishment success of invasive ring-necked and monk parakeets in Europe. J Biogeogr 36:2264-2278

Strubbe D, Broennimann O, Chiron F, Matthysen E (2013) Niche conservatism in non-native birds in Europe: niche-unfilling rather than niche-expansion. Glob Ecol Biogeogr 22(8):962-970. https://doi.org/10.1111/geb.12050

Thuiller W (2003) Biomod - optimizing predictions of species distributions and projecting potential future shifts under global change. Glob Chang Biol 9:1353-1362

Thuiller W, Araújo MB, Lavorel S (2004) Do we need land-cover data to model species distributions in Europe? J Biogeogr 31:353-361

Thuiller W, Lafourcade B, Engler R, Araújo MB (2009) BIOMOD - a platform for ensemble forecasting of species distributions. Ecography 32:369-373

Thuiller W, Georges D, Engler R, Breiner F (2016) biomod2: ensemble platform for species distribution modeling. R Core Team. https://cran.r-project.org/web/packages/biomod2/biomod2.pdf

Varela S, Anderson RP, García-Valdés R, Fernández-González F (2014) Environmental filters reduce the effects of sampling bias and improve predictions of ecological niche models. Ecography 37:1084-1091

Voous KH (1960) Atlas van de Europese vogels. Elsevier, Amsterdam

Warren DL, Glor RE, Turelli M (2010) ENMTools: a toolbox for comparative studies of environmental niche models. Ecography 33:607-611

Warren DL, Cardillo M, Rosaur DF, Bolnick DI (2014) Mistaking geography for biology: inferring processes from species distributions. Trends Ecol Evol 29(10):572-580

Webb CO, Ackerly DD, McPeek MA, Donoghue MJ (2002) Phylogenies and community ecology. Annu Rev Ecol Syst 33:475-505

Wiens JJ (2004) Speciation and ecology revisited: phylogenetic niche conservatism and the origin of species. Evolution 58:193-197

Wiens JJ (2008) Commentary on Losos (2008): Niche conservatism déjà vu. Ecol Lett 11:1004-1005

Wiens JJ, Graham CH (2005) Niche conservatism: integrating evolution, ecology, and conservation biology. Annu Rev Ecol Evol Syst 36:519-539

Wiens JJ, Ackerly DD, Allen AP, Anacker BL, Buckley LB, Cornell HV, Damschen EI, Davies TJ, Grytnes J-A, Harrison SP, Hawkins BA, Holt RD, McCain CM, Stephens PR (2010) Niche conservatism as an emerging principle in ecology and conservation biology. Ecol Lett 13:1310-1324

Zhu G-P, Peterson AT (2017) Do consensus models outperform individual models? Transferability evaluations of diverse modeling approaches for an invasive moth. Biol Invasions 19(9):2519-2532. https://doi.org/10.1007/s10530-017-1460-y

Open Access This chapter is licensed under the terms of the Creative Commons Attribution 4.0 International License (http://creativecommons.org/licenses/by/4.0/), which permits use, sharing, adaptation, distribution and reproduction in any medium or format, as long as you give appropriate credit to the original author(s) and the source, provide a link to the Creative Commons license and indicate if changes were made.

The images or other third party material in this chapter are included in the chapter's Creative Commons license, unless indicated otherwise in a credit line to the material. If material is not included in the chapter's Creative Commons license and your intended use is not permitted by statutory regulation or exceeds the permitted use, you will need to obtain permission directly from the copyright holder.

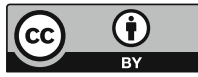

